\title{
VERSITA
}

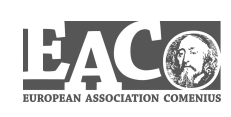

\section{EFFECTIVe Tax RATES IN THE MORAVIAN-SileSian REGION}

\section{Lenka Janíčková ${ }^{1}$}

\begin{abstract}
The aim of this work is to evaluate the effective corporate tax rate in the Moravian-Silesian Region in the Czech Republic on the basis of a backward-looking micro view. The results obtained are then compared with other methods of measuring the tax burden, especially with the corporate tax quota and effective corporate tax rate based on a backward-looking macro view and its components. The tax burden will be evaluated for the period 2007-2010 in order to capture the effects of the economic crisis. It is clear that the effective tax rate computed according to the backward-looking micro view and corporate tax quota confirms the results of a number of empirical studies because, in comparison to an effective marginal tax rate based on the macro view, they reflect fluctuations in business cycles.
\end{abstract}

\section{Keywords}

Effective Tax Rate, Corporation, Backward-Looking, Micro View

\section{Introduction}

The main difference between the state and other economic subjects is the manner in which it can influence the decision-making process of other subjects. The main tool of the state is fiscal policy, which is mainly implemented through the budget and is therefore connected with the creation of a tax system. A properly adjusted tax system enables the negative impact of economic cycles to be reduced, contributes to the growth of the economy or reduces the negative impact of market mechanisms on domestic subjects.

The aim of this work is to evaluate the effective corporate tax rate in the Moravian-Silesian Region on the basis of a backward-looking micro view. The results obtained will then be compared with other methods of measuring the tax burden, especially with the corporate tax quota and the effective corporate tax rate measured according to a backward-looking micro view.

\footnotetext{
${ }^{1}$ Faculty of Economics, VSB - Technical University of Ostrava, Sokolská tř. 33, 70121 Ostrava, Czech Republic. E-mail: lenka.janickova@vsb.cz.
} 
The organization of the paper will be as follows. The next section will introduce the main options available for measuring the tax burden. Section III will focus on the evaluation of effective corporate tax rates in the Moravian-Silesian Region and compare the results with an effective tax rate based on a backward-looking macro view and corporate tax quota. The final section summarizes the main findings.

\section{Literature review}

The evaluation and comparison of tax systems is an important economic topic, as taxation has an important influence on the decisions made by companies on investment or localization. The simplest way to evaluate tax systems is to use statutory tax rates. However, the results obtained do not take into account the complexity of tax systems (Blechová, 2008) or any analysis of the primary methods used to evaluate and compare the corporate tax burdens used in the European Union. The commonly used approaches are (i) statutory corporate tax rate, (ii) effective corporate tax rate and (iii) implicit tax rate. Many studies also provide an evaluation of the advantages and disadvantages of those approaches (e.g. OECD, 2000).

The available literature (e.g. Giannini and Maggiulli, 2002; OECD, 2000) provides a different way to calculate effective tax rates: backward-looking and forward-looking views. The main difference between these is the use of information. The backward-looking view uses ex-post real data for estimating the tax burden, while the forward-looking view applies statutory features of tax system for the evaluation of the tax aspects of decisions. Within the backward-looking view, it is possible to assess the macro and micro effective rates. Studies based on the macro rates usually use aggregated data and the final value is given as a fraction of paid corporate taxes to a tax base, which can be represented by, e.g. corporate gross operating surplus of aggregate corporate profit Nicodème (2001). For the calculation of the effective tax rate on a micro level, microeconomic data received from financial accounts are used. Široký (2012) states that three main ways of setting the effective tax rates on micro level are commonly applied. They are calculated as the rate of corporate income / profit taxes paid and of the tax base: 1 . total profit or loss before tax (i.e. profit on ordinary activities before tax + extraordinary income + extraordinary charges), 2. total operating income, 3. gross operating profit or loss (total operating revenues operating expenses - operating charges and taxes - personal expenses).

Similarly and Yin (2003) determines the main streams of U.S. empirical literature focusing on effective tax rates on a micro level. The first approach uses Schedule M-1 Data ${ }^{2}$. The second is to combine the Internal Revenue Service (IRS) ${ }^{3}$ and financial statement information. The third stream uses only financial statement information. The last approach mentioned in the literature uses data from National Income and Product Accounts, which provides an estimation of corporate profit based on IRS corporate taxable income.

\footnotetext{
${ }^{2}$ The M-1 Schedule is a reconciliation of the profit or loss reported on a company's books with the taxable income or loss reported on the tax return.

${ }^{3}$ The U.S. government agency which is responsible for tax collection and tax law enforcement.
} 
Blechová (2008) summarizes the commonly-mentioned advantages and disadvantages of different approaches to the evaluation of the effective tax rate. Dwenger and Steiner (2008) conclude that the effective tax rates assessed by backward-looking micro data provide some advantages. The calculations use real data, enable the study of the impact of taxes on different types of companies or the identification of components of financial statements which are influenced by taxes the most. On the other hand, this method does not enable the isolation of the effects of foreign taxes, because a number of companies perform their activities in other countries and finally the financial statements are a mix of features from different systems.

Effective tax rates based on a backward-looking micro view are used in a number of empirical studies. Nicodème (2001) applies data presented in the database of the Bank for the Accounts of Companies Harmonised which are provided by the European commission. The data obtained are used for the evaluation of effective tax rates in EU countries, the U.S. and Japan. The final values he analyses according to different company sizes and sectors. Dwenger and Steiner (2008) estimate the elasticity of taxable corporate incomes to corporate tax rate. The results are obtained from the financial statements of German companies during the period 1998-2001. The authors evaluate a portion of corporate taxes to adjusted gross income and the companies are divided according to the location of the headquarters and by the branch of economic activity. Buettner and Ruf (2004) calculated firm-level effective tax rates in Germany. The authors use the results obtained for the evaluation of the impact of taxation on decision-making in connection with direct investment. Yin (2003) determines the effective tax rates for public corporations in the U.S. for the period 1995-2000. The estimate is based on a comparison of the worldwide taxes paid by U.S. companies versus their worldwide book income. He finds out that there was a sharp drop in effective tax rates in the selected period.

\section{Tax burden in the Moravian-Silesian Region}

The next part of the paper will focus on the measurement of corporate effective tax rates based on a backward-looking micro view on the Moravian-Silesian Region in the Czech Republic in the period 2007-2010. The result will be compared with the tax burden of Czech entrepreneurs measured by the effective corporate tax rate based on a backwardlooking macro view and corporate tax quota.

The evaluation of effective tax rates will be performed by the method mentioned by, e.g. Široký (2012). The effective tax rate is calculated as the rate of corporate income to profit taxes paid and of the tax base. The tax base will be represented by (i) the total profit or loss before tax (i.e. profit on ordinary activities before tax + extraordinary income + extraordinary charges) and (ii) the gross operating profit or loss (total operating revenues operating expenses - operating charges and taxes - personal expenses). The required data are obtained from the financial statements of the companies, which are publicly available on the web pages of the business register. The basic set of observations is created from those companies with headquarters in the Moravian-Silesian Region. The companies in the sample are chosen according to quota sampling, which ensures a consistent structure 
of the basic set and sample. The chosen quotas are (i) the size of the company according to number of employees, (ii) the institutional sector, (iii) the sector of activity. The values obtained are used for the calculation of the effective tax rate according to Široký (2012) for each company. The data obtained are then aggregated to an effective corporate tax rate for the whole region. In the case of a company with zero paid taxes, the effective tax rate for this company is zero. This procedure is in accordance with the study of Dwenger and Steiner (2008).

Figure 1 shows the evolution of effective corporate tax rates calculated on the micro level for the Moravian-Silesian Region in the period 2007-2010. The results show that, from the early beginning of the economic crisis in 2007 to 2009 , there is a quite significant decrease in tax rates. The values reached bottom in 2009 , in the case of the total profit or loss before tax the received value moved to negative figures. According to the values obtained, it is also clear that the effective corporate tax rate in 2010 is nearly at the same level as before the economic crisis. Also quite important is the value of the median of the variables, which was calculated for the individual observed companies. These values show very similar development to the aggregate effective corporate tax rate. At the beginning of the crisis, a small increase can be seen and in 2009 there is also a noticeable decrease, which is, however, not so rapid and does not fall into negative values. Both in the case of the median of total profit or loss before tax and median for the gross operating profit or loss, the figures obtained are slightly smaller compared to the aggregated rates and show smaller fluctuations in their development.

Figure 1: Effective corporate tax rate (micro view), 2007-2010

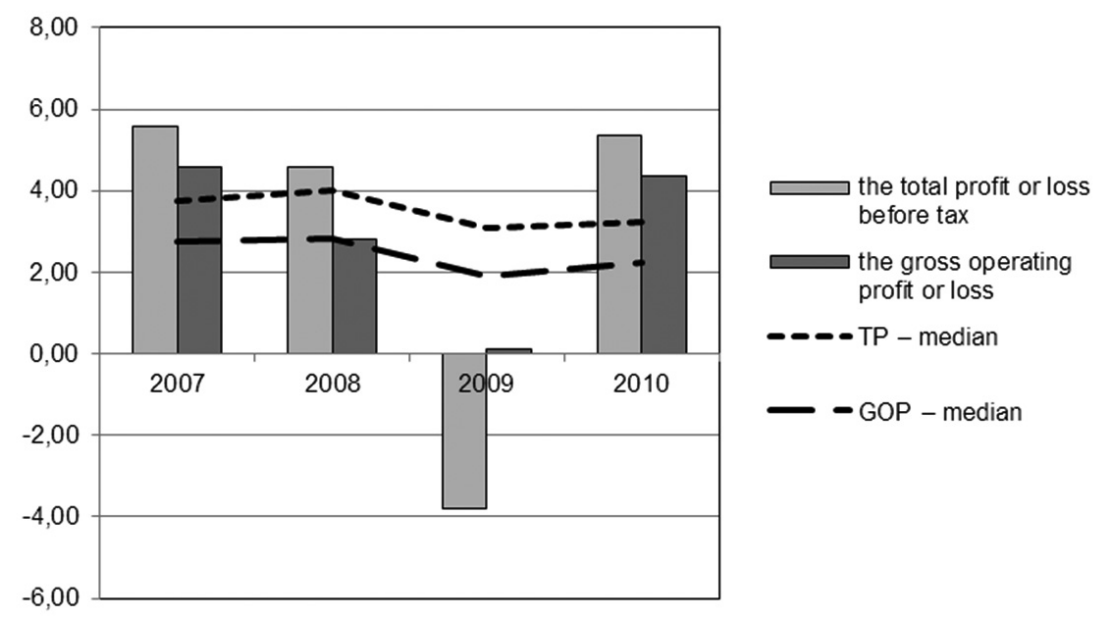

Source: Own calculation

Note: TP (total profit or loss before tax), GOP (gross operating profit or loss). 
If we look more closely at the values obtained, we can see that, during the economic crisis, there emerged differences in our sample. Before the crisis in 2007 and in the last year under observation (2010), the figures obtained are much more homogenous compared to the figures measured at the beginning of the crisis. The biggest differences in the effective corporate tax rates measured by a backward-looking micro view are apparent at the beginning of the economic crisis in 2008, where the standard deviation of the values is more than four times greater than in the previous period in the case of the total profit or loss before tax. In the case of the gross operating profit or loss, the same evolution can be observed, although it is, however, not so distinct. From this year on, there is tendency for the values measured by all methods to converge.

If we focus on the evolution of the taxes paid by corporations, it is clear that there was, at the beginning of the economic crisis, a small increase in the taxes collected in the Moravian-Silesian Region, but in 2009 there is quite a noticeably sharp decrease of this variable.

The next part of the paper will compare the values of effective corporate tax rates obtained by a backward-looking micro view for the Moravian-Silesian Region with the effective corporate tax rates obtained by a backward-looking macro view and with the corporate tax quota computed for the Czech Republic and for the Moravian-Silesian Region.

Another method of measuring the tax burden is to use an effective tax rate based on the backward-looking macro view. Contrary to a micro view, selected parts of the corporate tax legislation are used for its evaluation. This methodology was introduced by Devereux and Griffith (1999). The authors evaluate hypothetical investment localized to the home and host country. Using required real income after taxation, enables them to evaluate required income before taxation. In the process, they consider investment in the five different financial assets (intangible assets, industrial buildings, machinery, financial assets, inventory) and three different sources of financing (retained earnings, new equity, debt). The detailed methodology of an effective tax rate based on a backward-looking macro view is presented in Devereux et al. (2011). In the process of their calculations, the authors diversified the effective corporate marginal tax rate (EMTR) and effective corporate average rate (EATR).

As said above, the evaluation is based on selected parts of legislation. Those parts, and their development in the Czech Republic as used in the calculations, are represented in Appendix A. Unlike the backward-looking micro view, there is no way to differentiate effective tax rates for the specific region of the country if this region has the same legislative treatment of taxes as the whole country. The data representing effective corporate tax rate for the Czech Republic are obtained from Devereux et al. (2011) and are displayed in Figure 2. 
Figure 2: Effective corporate tax rate (macro view), 2007-2010

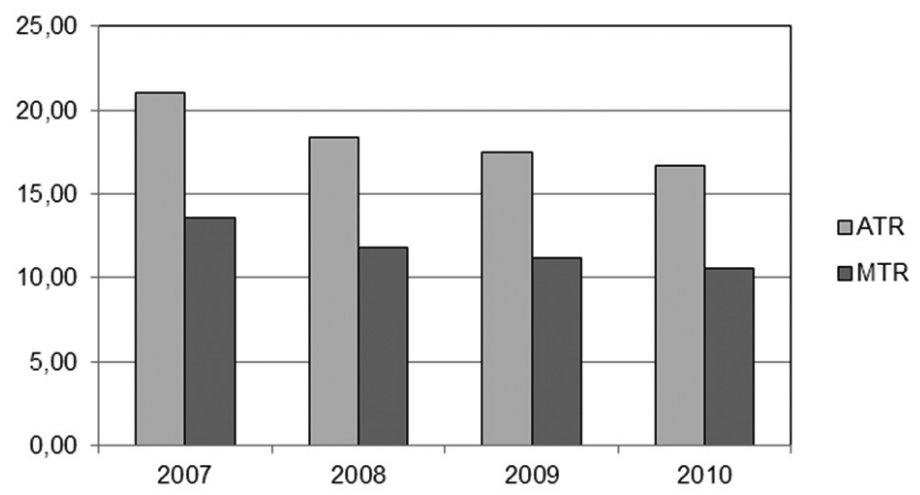

Source: Devereux et al. (2011)

Unlike the values obtained by the micro view, the EATR and EMTR decrease during the entire period under observation. To this is added Table 1, which reflects the trend of the EATR and EMTR partial components. It is obvious that these values are also decreasing and at the end of the period under observation they are smaller by about 3.4 p.p. on average. A completely different trend shows the component of debt financing of potential investment which has negative values, and is increasing over time. Lammersen and Schwager (2005) state that these negative values are partly the result of the fact that the cost of capital is lower than the real interest rate and this suggests that the state can indirectly support investment with taxes which increase the rate of profit after-taxation above the rate of profit before-taxation.

Table 1: Effective corporate tax rate - components (macro view), 2007-2010

\begin{tabular}{rrrrrrrrr}
\hline & IBATR & INATR & MAATR & FAATR & INVATR & REATR & NEATR & DBATR \\
\hline 2007 & 20.1 & 20.2 & 19.1 & 23.4 & 22.3 & 23.9 & 23.9 & 15.6 \\
2008 & 17.6 & 17.6 & 16.7 & 20.5 & 19.5 & 20.9 & 20.9 & 13.6 \\
2009 & 16.8 & 16.8 & 15.9 & 19.5 & 18.5 & 20.0 & 20.0 & 13.0 \\
2010 & 16.0 & 16.0 & 15.1 & 18.5 & 17.6 & 19.0 & 19.0 & 12.4 \\
\hline & IBMTR & INMTR & MAMTR & FAMTR & INVMTR & REMTR & NEMTR & DBMTR \\
\hline 2007 & 9.9 & 10.2 & 5.4 & 22.2 & 18.3 & 23.8 & 23.8 & -14.6 \\
2008 & 8.7 & 8.7 & 4.6 & 19.4 & 15.9 & 20.8 & 20.8 & -12.0 \\
2009 & 8.3 & 8.2 & 4.4 & 18.4 & 15.1 & 19.9 & 19.9 & -11.1 \\
2010 & 8.2 & 7.8 & 4.1 & 17.5 & 14.3 & 18.9 & 18.9 & -10.3 \\
\hline
\end{tabular}

Source: Devereux et al. (2011)

Note: According to financing: eatr of industrial buildings - ibatr, eatr of intangibles - inatr, eatr of machinery - mamtr, eatr of financial assets - faatr, eatr of inventory - invatr; emtr of industrial buildings - ibmtr, emtr of intangibles - inmtr, emtr of machinery - mamtr, emtr of financial assets famtr, emtr of inventory - invmtr;

According to the source of financing: eatr of retained earnings - reatr, eatr of new equity - neatr, eatr of debt - dbatr; emtr of retained earnings - remtr, emtr of new equity - nemtr, emtr of debtdbmtr. 
The development of the effective corporate tax rate measured by backward-looking micro and macro views confirm the results of the empirical studies, which point out that the micro view is much more predisposed to reflect the development of the business cycle compared to the macro view (e.g. Blechová, 2008). The results also show that the tax burden measured by the backward-looking micro view is considerably smaller compared to the results obtained by the backward-looking macro view, with one exception - the effective marginal corporate tax rate for machinery and for debt.

The third option for the measuring of the tax burden used in this paper is a tax quota which is calculated only for corporate taxes. Figure 3 shows the development of a simple tax quota for corporate tax which is computed as a share of corporate tax paid into the gross domestic product of the Czech Republic. The corporate tax quota for the MoravianSilesian region is assessed similarly, with numbers representing the collected corporate taxes in this region used for the evaluation and the values obtained from the Ministry of Finance. The results obtained show that the share of corporate tax revenues in the Moravian-Silesian Region is similar to the same index assessed for the Czech Republic as a whole.

Figure 3: Corporate tax quota, 2007-2010

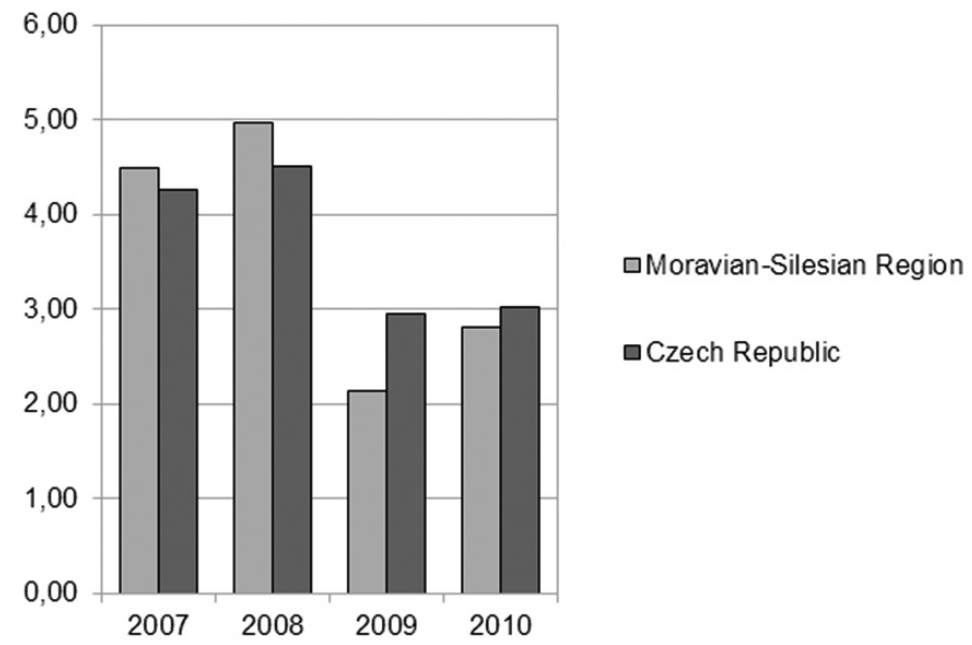

Source: Czech Statistical Office, Ministry of Finance of the Czech Republic, own calculations

From figure 3 it can be seen that the evolution of the corporate tax quota is similar to the effective corporate tax rate based on a backward-looking micro view. Unlike the effective corporate tax rate, the corporate tax quota is growing in 2008, with the decrease noticeable one year later, in 2009. The next year there is slight increase of this indicator, which is similar to the evolution of the effective tax rate. Also, the absolute values of the corporate tax quota are similar to the effective tax rate based on a backward-looking micro view. 


\section{Conclusion}

Tax cooperation between EU member countries was established at the beginning of that community in the 1950s, with a focus mainly on indirect taxes. EU activity related to the area of direct taxes is aimed at corporate taxes. Nevertheless, the harmonisation of this tax is still slow and the European Commission remains mainly involved in less than successful proposals, while the EU member countries are mainly autonomous in this area (see e.g. Janíčková, 2012).

In this context, the question arises as to whether the tax burden is the same for companies within different regions in the same country. This contribution tried to answer this problem for the case of those companies in the Moravian-Silesian Region in the Czech Republic. For this purpose, three different methods for evaluating the tax burden were used the effective corporate tax rate based on a backward-looking micro view, the effective corporate tax rate based on a backward-looking macro view (and its components) and the corporate tax quota.

The effective corporate tax rate based on a backward-looking micro view and corporate tax quota reached the same level of tax burden in the region. Also, their development in the chosen period is similar. At the beginning of the economic crisis they slightly rise. Due to the impact of the crisis on economic subjects in the Czech Republic, their value then sharply decreases. The disadvantage of both indicators is that they reflect the current business cycle of the economy. The third indicator used, the effective corporate tax rate based on backward-looking macro view uses selected parts of the tax legislation. Contrary to the previously used indexes, this one decreases through the whole observed period, but its values are considerable higher.

\section{Acknowledgements}

The paper was supported by the VSB - Technical University of Ostrava SGS research project SP2012/105 "The influence of investment incentives within the tax policy of the Czech Republic on enterprises in the Moravian-Silesian Region in the context of the economic crisis".

\section{References}

Blechová, B. (2008). Charakteristika př́ístupů používaných v EU pro hodnocení efektivního daňového zatîžení př́ijmů korporací [Characteristics of the Approaches Used in the EU for the Evaluation of the Effective Tax Burden on Corporate Income]. In Teoretické a praktické aspekty veřejných financí [Theoretical and Practical Aspects of Public Finance]. Praha: VŠE Praha, Oeconomica.

Brüttner, T., Ruf, M. (2004). Tax Incentives and the Location of FDI: Evidence from a Panel of German Multinationals. ZEW Discussion Papers, No. 047-76. ECONSTOR. Devereux, M.P., Elschner, Ch., Endres, D., Spengel, Ch. (2011). Effective Levels of Company Taxation within an Enlarged EU (second update). Intermediate Report 2011, TAXAUD/2008/CC/099. 
Devereux, M. P., Grifith, R. (1999). The Taxation of Discrete Investment Choices. Working Paper No. 98/16 (Revision 2). London: Institute for Fiscal Studies.

Dwenger, N., Steiner, V. (2008). Effective Profit Taxation and the Elasticity of the Corporate Income Tax Base: Evidence from German Corporate Tax Return Data. DIW Berlin Discussion Paper No. 829.

Giannini, S., Maggiulli, C. (2002). The Effective Tax Rates in the EU Commission Study on Corporate Taxation: Methodological Aspects, Main Results and Policy Implications. CESifo Working Paper No. 666 (1).

Janíčková, L. (2012). Daňová harmonizace - možná cesta z krize? [Tax Harmonization - Possible Way Out of the Crisis?]. Český finanční a účetní časopis [Czech Finance and Accounting Journal], 7(1), 64-81.

Lammersen, L., Schwager, R. (2005). The Effective Tax Burden of Companies in European Regions: An International Comparison. ZEW Economic Studies.

Nicodème, G. (2001). Computing Effective Corporate Tax Rates: Comparisons and Results. MPRA Paper No. 3808.

OECD (2000). Tax Burdens - Alternative Measures. Paris: OECD.

Široký, J., Kvíčalová, J., Valentová, I. (2012). Identification of Causes of Differences in Statutory and Effective Rates of Corporate Taxes. Acta Universitatis Agriculturae et Silviculturae Mendelianae Brunensis, 60(2).

Yin, G. K. (2003). How Much Tax Do Large Public Corporations Pay?: Estimating the Effective Tax Rates of the S\&P 500. Virginal Law Review, 89(8), 1793-1856. 


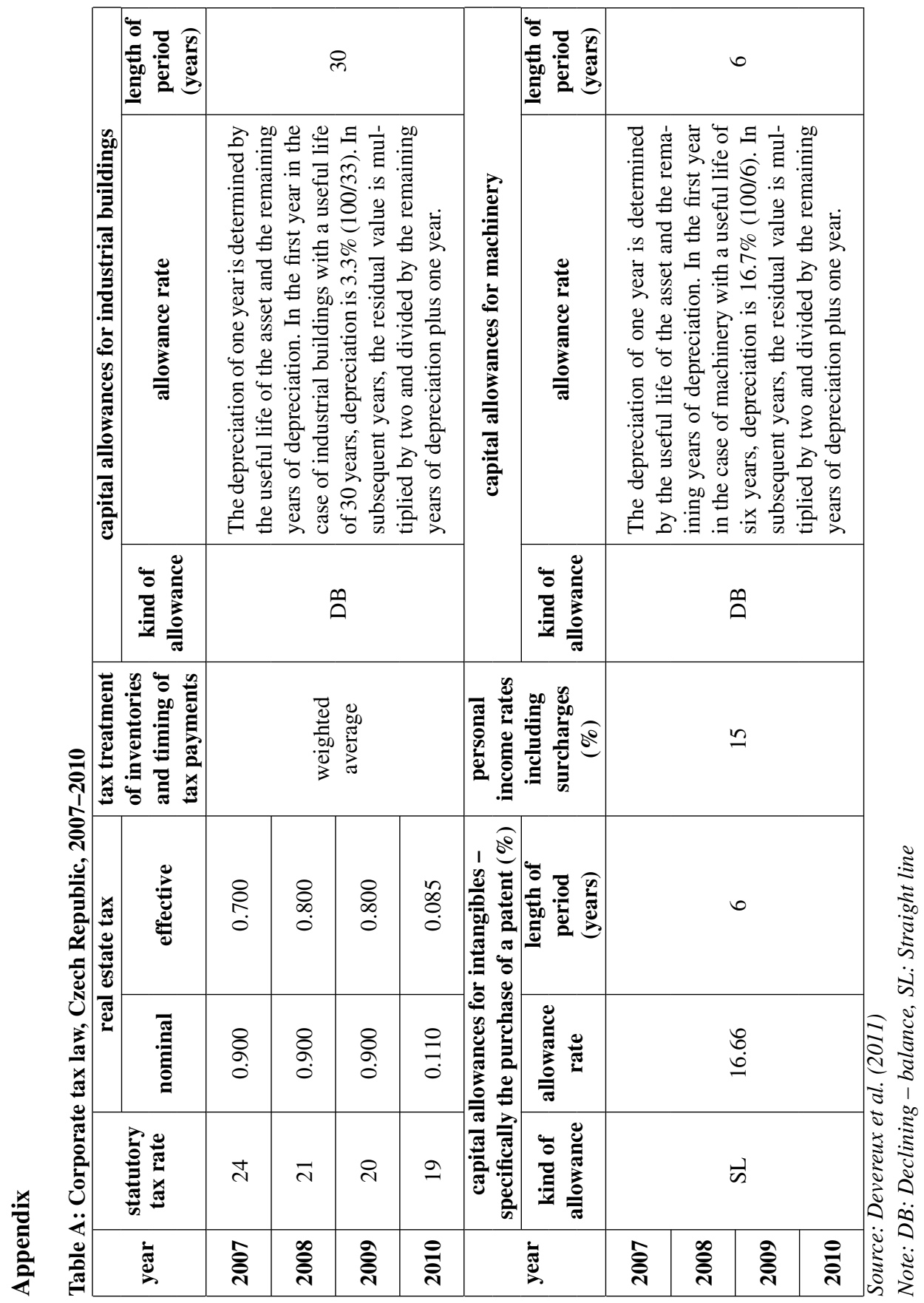

